九州大学学術情報リポジトリ

Kyushu University Institutional Repository

\title{
SYSTEMATIC STUDIES ON PROCTOTRUPOID AND CHALCIDOID PARASITES OF GALL MIDGES INJURIOUS TO PINUS AND CRYPTOMERIA IN JAPAN AND KOREA (HYMENOPTERA)
}

Yoshida, Nariaki

Hirashima, Yoshihiro

https://doi.org/10.5109/2395

出版情報: ESAKIA. 14，pp.113-133，1979-11-15. Entomological Laboratory，Faculty of Agriculture, Kyushu University バージョン :

権利関係 : 


\title{
SYSTEMATIC STUDIES ON PROCTOTRUPOID AND CHALCIDOID PARASITES OF GALL MIDGES INJURIOUS TO PINUS AND CRYPTOMERIA IN JAPAN AND KOREA (HYMENOPTERA)*
}

\author{
NARIAKI YOSHIDA \\ Kyushu Branch, Forestry and Forest Products Research \\ Institute, Kumamoto 860, Japan \\ and \\ YOSHIHIRO HIRASHIMA \\ Entomological Laboratory, Faculty of Agriculture \\ Kyushu University, Fukuoka 812, Japan
}

\begin{abstract}
Seven species of Hymenopterous wasps parasitic to three species of gall midges injurious to Pinus and Cryptomeria are discussed, five of which are described as new. New species are Inostemma matsutama and Platygaster matsutama parasitic to Thecodiplosis japonensis, Platygaster sugitama and Gastrancistus sugitama parasitic to Contarinia inouyei, and Synopeas zaitama parasitic to Resseliella odai. Isostasius seoulis Ko is transferred to Inostemma.

Scanning microscopic photographs of all parasites discussed are provided in order to facilitate the precise identification of these tiny but economically important species. Biological notes of these Hymenopterous parasites are also given.
\end{abstract}

This paper deals with Hymenopterous parasites associated with three important species of gall midges injurious to Pinus and Cryptomeria in Japan and Korea.

The pine needle gall midge or matsuba-no-tamabae, Thecodiplosis japonensis Uchida et Inouye, is one of the most serious pests of pines, Pinus densiflora and Pinus thunbergii in Japan and Korea. In Japan, outbreaks of this gall midge were observed on Tsushima (Nagasaki Prefecture) from 1939 to 1970, on Okinoshima (Shimane Prefecture) from 1940 to 1960, in Ishikawa Prefecture from 1959 to 1965 and in Hiroshima Prefecture from 1963 to 1974. Local damages to the pine trees are still observed at present in Kyushu and in some

* Contribution from the Entomological Laboratory, Faculty of Agriculture, Kyushu University, Fukuoka (Ser. 3, No. 67). 
areas of Toyama, Niigata, Yamagata and Akita Prefectures faced to the Japan Sea. A number of papers have been published in relation to the control of this pest. Yasumatsu (1961), Miura (1962), Yamada (1963), Kato (1964), Matsueda (1966), Kuranaga, Yoshida and Morimoto (1972, 1973, 1976) and Kuranaga $(1974 \mathrm{a}, \mathrm{b})$ are some of those who worked on the biological control of the pine needle gall midge.

In Korea, the outbreak of the pine needle gall midge is so extensive that the control of this pest has been become one of the most serious social problems because of the importance of the pine tree (chiefly Pinus densiflora in this case) in forestry and conservation. Its outbreak has been observed for the last 20 years, which was originated in the Moppo area, a south-western part of Korea. Since then, a great deal of effort has been paid for its control. J. H. Ko $(1963,1965,1966,1971)$ is working on the biological control of this pest extensively.

For the natural control agency of the pine needle gall midge, three species of Hymenopterous parasites and two species of them have been recorded in Japan and Korea, respectively. These wasps are studied comprehensively in this paper for the first time. As shown in the systematic section below, these are recognized as three species, Inostemma seoulis (Ko), Inostemmamatsutama sp. n. and Platygaster matsutama sp. n. Of these, Inostemma seoulis and Platygaster matsutama are widespread in Japan and Korea, but Inostemma matsutama is found only in an limited area of Kyushu so far.

In addition to the pine trees, the Japanese cedar or sugi, Cryptomeria japonica, is also one of the most important forest trees in Japan. This species grows only in Japan and China. In Japan, two species of gall midges are known to be injurious to sugi. They are the sugi needle gall midge or sugitamabae, Contarinia inouyei Mani, which attacks sugi needles as is suggested by its common name, and the sugi pitch midge or sugizai-no-tamabae, Resseliella odai (Inouye), which bores into the trunk of the sugi tree. The former pest occurs throughout Japan while the latter is restricted to southern part of Kyushu, most destructive in Miyazaki, Kagoshima, Kumamoto and Oita Prefectures. Hymenopterous parasitoids are also involved in the control of the two sugi gall midges. Tetrastichus sugitamabae Yasumatsu et Yoshii is said to be the most important parasite of this gall midge. We describe two more species of Hymenopterous parasites of this pest which have been detected chiefly by entomologists at the Kyushu Branch of the Forestry and Forest Products Research Institute, Kumamoto.

Another gall midge injurious to the Cryptomeria, the sugi pitch midge or sugizai-no-tamabae, Resseliella odai (Inouye), which was transferred from Thomasiniana is a local pest of sugi founded in southern part of Kyushu as stated before, although it is quite destructive. In 1976, a wasp parasitic to this gall midge was discovered at Ebino, Mt. Kirishima, by Mr. T. Sanui of Miyazaki 
Forest Experiment Station. This species is also treated in this paper.

Scanning microscopic photographs of all the parasites discussed in this paper are provided in order to facilitate the precise identification of these tiny but economically important species. Thus, the present paper provides the latest biological as well as detailed morphological informations of all the Hymenopterous parasites known to us of the three gall midges injurious to the pine and sugi trees in Japan and Korea.

It is also noted herewith that the identity of Japanese and Korean material of Thecodiplosis japonensis was confirmed by Dr. Yukawa of Kagoshima University (personal communication).

Acknowledgement: We are grateful to Mr. Kenzo Yamagishi of Kyushu University for his valuable discussions on the systematics of the Hymenopterous parasites involved and for literature. We are also grateful to Dr. Katsura Morimoto of Kyushu University for his useful discussions on the biology of Irostemma and Platygaster and informations on the biological control of matsuba-no-tamabae. Mr. Je Ho Ko of the Forest Experiment Station, Seoul, Korea, kindly invited Hirashima to Korea in 1977 in order to promote the biological control of matsuba-no-tamabae and provided him with a series of valuable specimens of Inostemma and Platygaster. We are grateful to him. Thanks are also due to Mr. Zentaro Kuranaga of the Kyushu Branch, Forestry and Forest Products Research Institute, Kumamoto and Mr. Takayoshi Sanui of Miyazaki Forest Experiment Station, Miyazaki for their kind cooperation in providing us with valuable material. We are also thankful to Dr. J. Yukawa of Kagoshima University for identification of matsuba-no-tamabae.

I. Wasps PA Rasitic to Thecodiplosis japonensis, OR MATSUBA-NO-TAMABAE

Proctotrupoidea : Platygasteridae

(1) Inostemma seoulis (Ko), comb. n. (Figs. I-7)

Japanese name : マッタマヤドリクロコバチ

Isostasius seoulis Ko, 1965, Res. Rep. Office Rural Devel., Suwon, 8 (2) : 91.

Although this species was originally described under the genus Isostasius, morphological characters clearly show that this species belongs to Inostemma. Inostemma seoulis is one of few interesting Inostemma species which do not have a prolonged horn on the tergite $\mathrm{I}$.

Recent studies prove that Inostemma and Isostasius are separated as follows (Yamagishi, personal communication) :

$$
\text { Inostemma }
$$

Scutellum trapezoidal, angulate

postero-laterally.

Parapsidal furrows present.

Lateral ocelli close to compound eyes.
Isostasius

Scutellum rounded and semicircular posteriorly.

Parapsidal furrows absent.

Lateral oceli rather apart from compound eyes. 
Tergite I more or less long, at least slightly swollen dorsally.

Tergite II not very long, about half as long as abdomen.
Tergite I short, not convex dorsally.

Tergite II very large, at least twothirds as long as abdomen.

\section{Redescription of female}

Length : 1.28-1. $72 \mathrm{~mm}$.

Color: Body black; antenna dark brown, apical half of scape yellow ; legs yellowish brown except coxae which are black; femora darker.

Head : Transverse in front view; height in front view: length in top view: width, $0.33: 0.22: 0.4$; face slightly convex in front ; eye moderate, height : width, $0.2: 0.185$; lateral ocelli nearly circular ; POL (distance between post ocelli) : LOL (distance between front and post ocelli) : OOL (distance between post ocellus and compound eye), $0.11: 0.06: 0.035$; mandible bidentate ; maxillary palpus 2-segmented. Antenna inserted just above clypeus, 10-segmented; length : width of each antenna1 segment, I $0.271: 0.074$, II 0.069 : 0.035, III 0. $067: 0.033$, IV $0.052: 0.033$, V $0.039: 0.03$, VI $0.03: 0.03$, VII $0.041:$ 0.043 , VIII $0.056: 0.054$, IX $0.054: 0.052$, X $0.08: 0.043$; club 4 -segmented but not distinct.

Thorax: Ratio of length: height: width across tegulae as $0.51: 0.35: 0.38$; mesonotum with notauli complete, broader posteriorly; median lobe of mesonotum rounded apically, with three to four longitudinal striae on apical $1 / 4$; scutellar foveae with scale-like waxy structure ; scutellum with postero-lateral corners angulate (Fig. 5), posterior margin broadly rounded ; flenul groove deep and wide; mesopleuron with broad impressed area in middle; metapleuron pubescent. Forewing with a subcostal vein which is almost straight and knob-like at distal end, reaching $1 / 3$ the length of forewing; length: width of forewing, $0.94: 0.4$; length : width of hindwing, $0.86: 0.17$. Tarsi 5 -segmented.

Abdomen: Ratio of length and width of each tergite, I $0.13: 0.15$, II 0.38 : 0 . 36, III $0.05: 0$. 31 , IV $0.06: 0.27$, V $0.06: 0$. 21 , VI $0.12: 0.16$; tergite I slightly swollen dorsally (Figs. 1 and 2 ) ; tergite VI triangular and pointed apically.

\section{Redescription of male}

Length : $1.25-1.65 \mathrm{~mm}$.

Similar to female except for antenna and abdomen. Length: width of antennal segments, I $0.252: 0.054$, II $0.054: 0.039$, III $0.061: 0.033$, IV 0.078 : 0.033 , V 0. $037: 0.030$, VI $0.054: 0.039$, VII $0.061: 0.064$, VIII $0.056: 0.041$, IX $0.054: 0.039, \mathrm{X}$ 0.093: 0.035. Length : width of abdominal tergites, I 0.15 : 0. 14, II $0.37: 0$. 33, III $0.06: 0.32$, IV $0.05: 0.27$, V $0.04: 0.23$, VI $0.035: 0.2$, VII $0.03: 0.13$. Tergite VII rounded apically.

Specimens examined: A long series of male and female specimens bred from the larvae of Thecodiplosis iaponensis collected in Japan and Korea. 

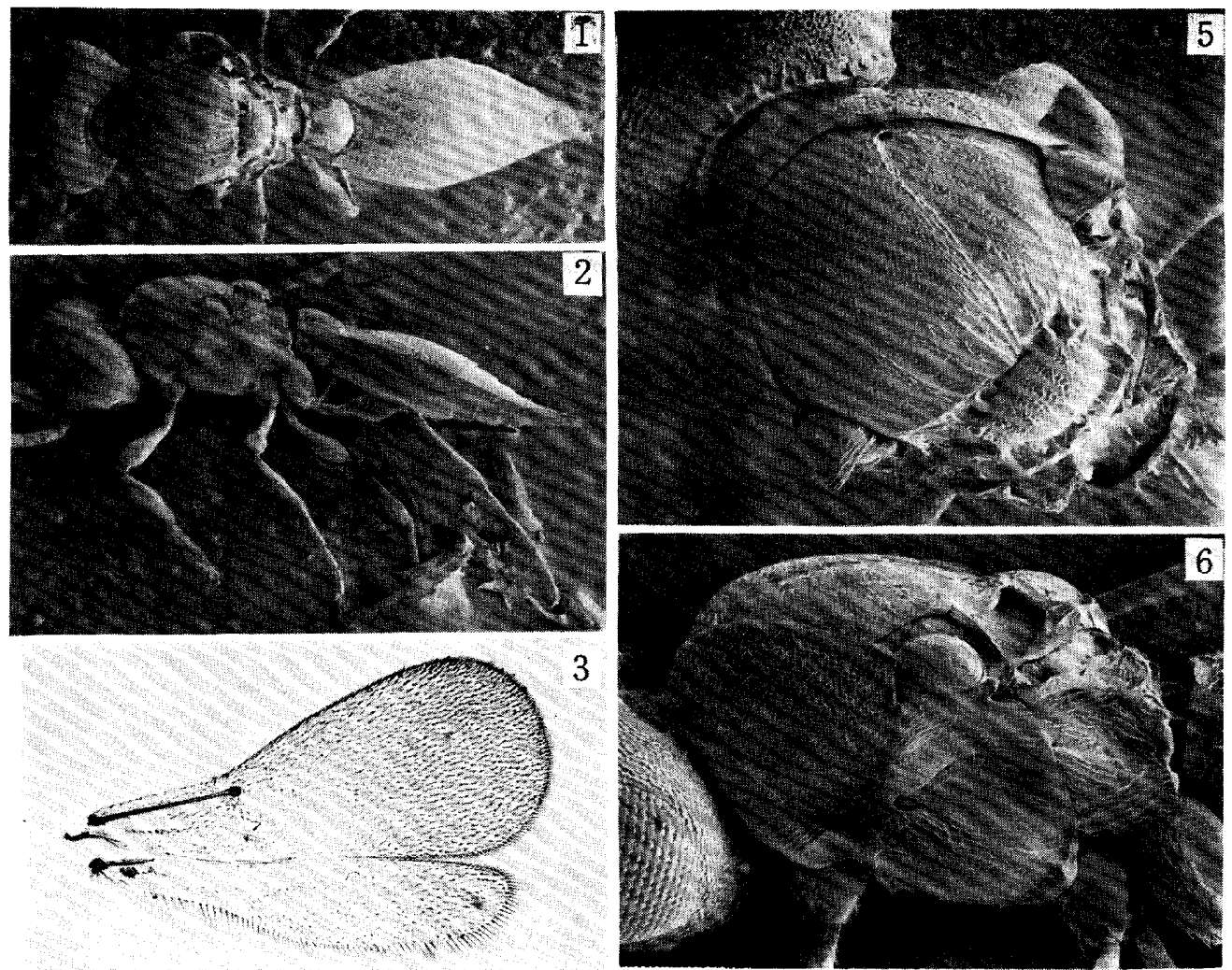

3
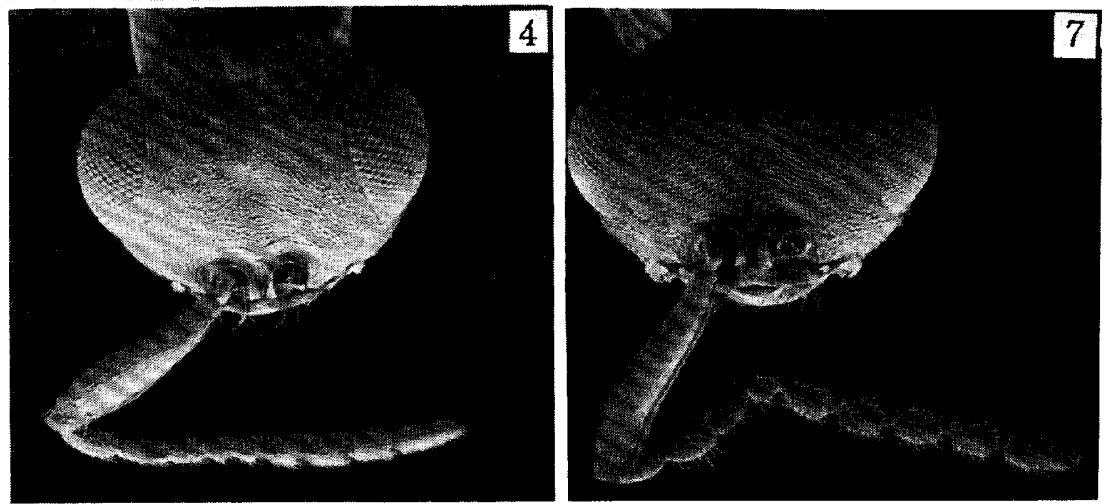

Figs. 1-7. Inostemma seouits (Ko). 1: Dorsal view of the female. 2: Lateral view of the female. 3: Wings. 4: Head and antenna (the left one is omitted) of the female. 5: Dorsal view of the female thorax. 6: Lateral view of the female thorax. 7: Head and antenna (the left one is omitted) of the male. 
Distribution: Korea and Japan (Kyushu, Honshu, Hokkaido). This species was originally described based on the material taken in Korea and Japan.

BIOLOGY: The life history of this wasp was studied by Ko (1966). The following note was derived from him. This species has one generation a year which is synchronized with its host. The adult wasp emerges from mid-June to mid-July with the peak of emergence in late-June. More adult emerges in the afternoon than in the morning. The sex ratio was 0.27 in the field. The longevity of male adult was 2 days and that of female 4 days. The number of eggs found in one female ovary was 462 on an average. The adult wasps deposit their eggs mostly in the newly hatched host larvae, Although a number of wasp's larvae are found living in one host larva, only one adult wasp emerges. This parasite overwinters in the 1st instar larval stage within the host larva in the soil.

Our observation of the life cycle of this species in Kyushu is very close to that described by Ko.

\section{(2) Inostemma matsutama, new species (Figs. 8-14)}

Japanese name：マッタマヤドリクロコブコバチ

\section{F emale}

Length :1.5- $1.9 \mathrm{~mm}$.

Color: Body black; antenna dark brown, with both ends of scape yellow. ish; legs yellowish brown except coxae which are blackish ; femora darker.

Head: Transverse in front view; height in front view : length in top view : width, $0.33: 0.25: 0.46$; face slightly convex in front ; eye moderate, height : width, $0.21: 0.18$; lateral ocelli rather crescent ; POL: LOL : OOL, 0.14 : 0 . 075 : 0. 029; mandible bidentate ; maxillary palpi very short, 2 -segmented. Antenna inserted just above clypeus, lo-segmented, length : width of each segment, I $0.26: 0.05$, II $0.082: 0.028$, III $0.076: 0.024$, IV $0.054: 0.028$, V 0.032 : 0. 022, VI 0. $03: 0.03$, VII 0. 04: 0. 04, VIII 0. $05: 0.044$, IX $0.048: 0.042$, X $0.07:$ 0 . 04; club 4-segmented but not distinct.

Thorax: Ratio of length : height : width across tegulae, $0.47: 0.41: 0.64$; mesonotum with notauli complete, broader posteriorly; median lobe of mesonotum pointed posteriorly and with a fine stria; scutellar foveae with scalelike waxy structure ; scutellum with anterior and posterior margins more angled than in Inostemma seoulis; flenul groove deep and wide ; mesopleuron with a broad impressed area in middle; metapleuron pubescent. Forewing with a subcostal vein which is almost straight and knob-like at distal end, reaching $1 / 3$ the length of forewing; length : width of forewing, $1.1: 0.45$; length : width of hindwing, $0.92: 0.2$. Tarsi 5 -segmented.

Abdomen: Ratio of length : width of each tergite, I $0.13: 0.2$, II 0.43 : 0. 43, III $0.05: 0.4$, IV $0.06: 0.34$, V $0.06: 0.25$, VI $0.19: 0.19$; tergite I with a 

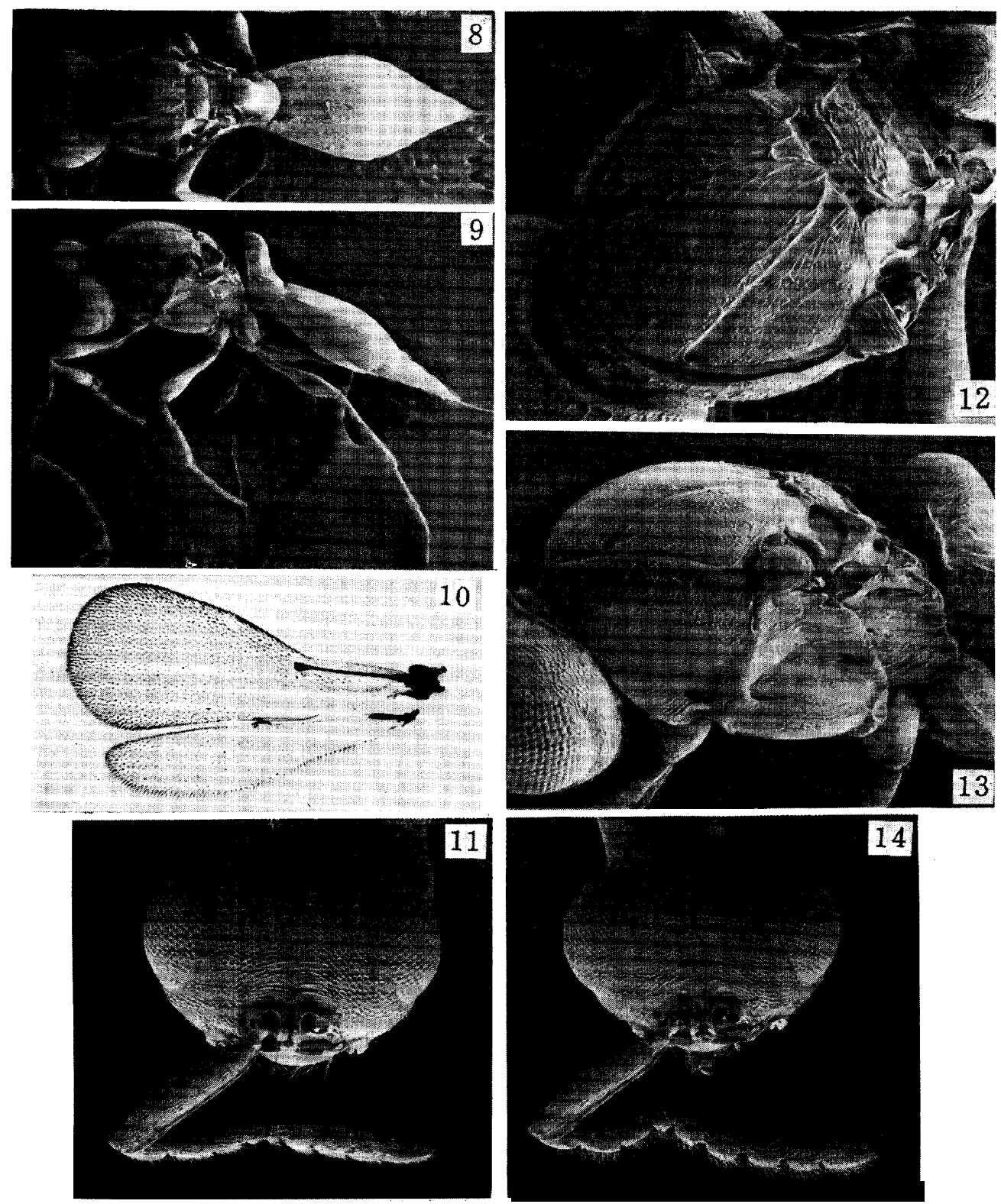

Figs. 8-14. Inostemma matsutama, new species. 8: Dorsal view of the female. 9: Lateral view of the female. 10: Wings. 11: Head and antenna (the left one is omitted) of the female. 12: Dorsal view of the female thorax. 13: Lateral view of the female thorax. 14: Head and antenna (the left one is omitted) of the male. 
short horn-like process (Figs. 8 and 9), which is not seen in Inostemma seoulis; anterior length : width of the process, $0.12: 0.13$; tergite VI triangular, pointed apically.

\section{Male}

Length :1. 4- $1.7 \mathrm{~mm}$.

Similar to female except antenna and abdomen. Ratio of length to width of each antenna1 segment, I $0.26: 0.058$, II $0.05: 0.035$, III $0.073: 0.035$, IV $0.065: 0.038$, V $0.045: 0.033$, VI $0.063: \mathbf{0 . 0 3 3}$, VII $0.035: 0.11$. Unlike female, tergite I without process. Tergite VII rounded apically.

Type material: Holotype female (Type No. 2161, Kyushu Univ.), 1 paratopotype female and 4 paratopotype males, emerged on 2. VIII. 1976 (reared at $15^{\circ} \mathrm{C}$ ), from $T$.japonensis, Tatsudayama, Kumamoto City, Kyushu (Z. Kuranaga) ; 3 paratopotype females, 13. VII. 1976 ( $Z$. Kuranaga) ;2 paratype females, Ashikita, Kumamoto Pref., Kyushu, 27. VI. 1975 (Z. Kuranaga) ; 4 paratype females and 3 paratype males, 4. VII. 1975, 4 paratype females and 4 paratype males, 8. VII. 1975, 4 paratype males, 2. VII. 1975, and 1 paratype male, 27. VI. 1975, same locality as above, all were collected by Z. Kuranaga.

Distribution : Japan (Kyushu).

Diagnosis: The female of the new species differs markedly from that of Inostemma seoulis in having the horn, which is not very long, however, on the tergite I. Males of both species, however, are very similar because, unlike the females, the male of Inostemma matsutama does not have such a horn on the tergite I. They are separable by the median lobe of mesonotum which is provided on the apical $1 / 4$ with a fine stria only in matsutama but with three to four striae in seoulis.

Brology: The life cycle of this species is very similar to that of Inostemma seoulis. The female of this wasp also oviposits on the 1st instar larva of the host.

\section{(3) Platygaster matsutama, new species (Figs. 15-21)}

Japanese name: マッタマヤドリハラビロコバチ

\section{Female}

Length : $1.2-1.75 \mathrm{~mm}$.

Color: Body black, shining; antenna reddish brown; legs reddish brown to yellowish brown except coxae which are darker.

Head: Transverse in front view; length in top view : height in front view : width, $0.22: 0.35: 0.43$; POL : LOL :OOL, $0.13: 0.038: 0.045$. Antenna 10segmented, length : width of each segment, I $0.308: 0.072$, II $0.08: 0.035$, III $0.026: 0.028$, IV $0.059: 0.039$, V $0.056: 0.033$, VI $0.069: 0.041$, VII $0.074: 0.046$, VIII $0.056: 0.048$, IX $0.056: 0.046, \quad$ X $0.095: 0.043$.

Thorax: Stout, length : height: width across tegulae, $0.55: 0.43: 0.37$; pro- 

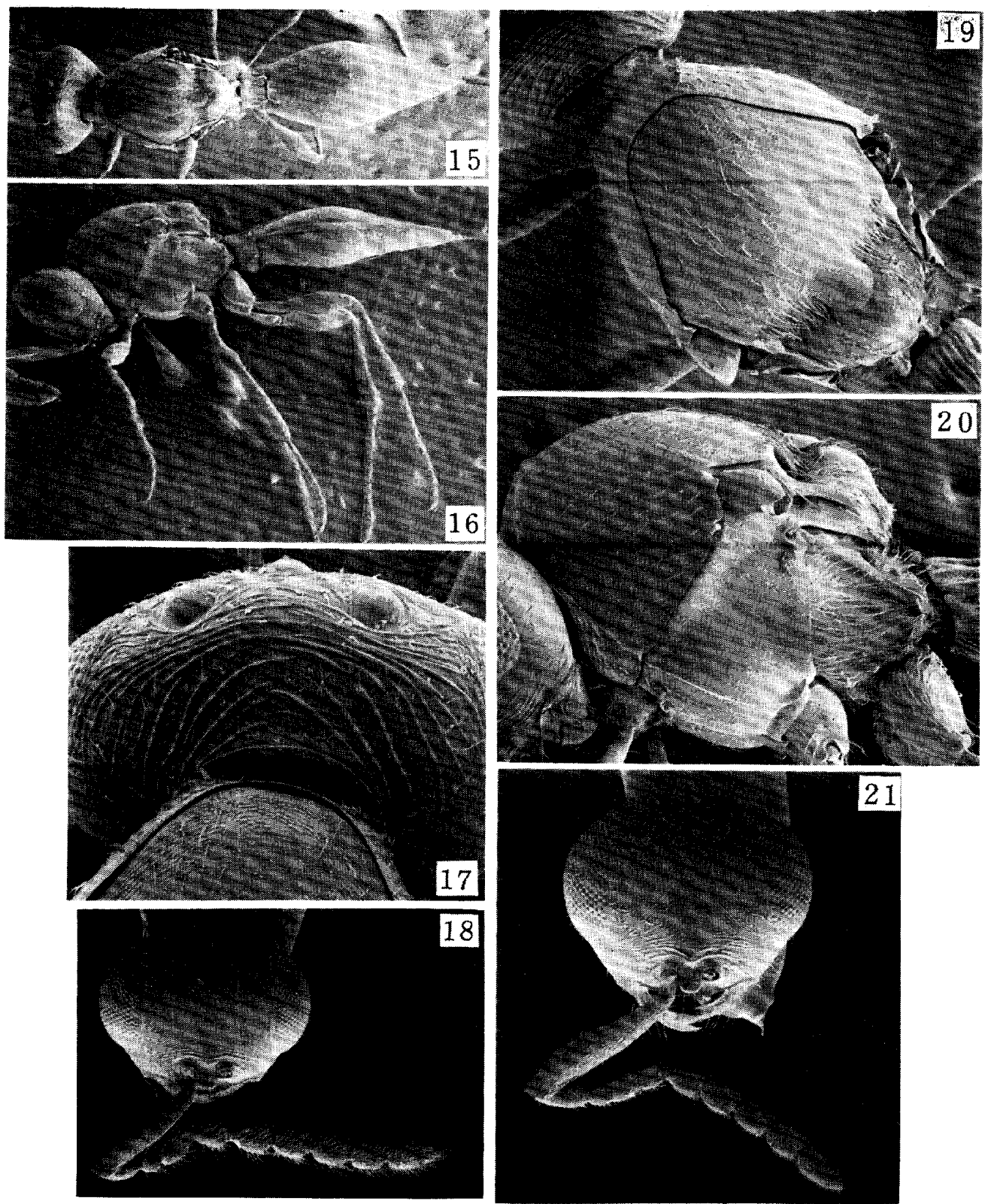

Figs. 15-21. Platygaster matsutama, new species. 15: Dorsal view of the female. 16: Lateral view of the female. 17: Occiput of the male. 18: Head and antenna (the left one is omitted) of the male. 19: Dorsal view of the female thorax. 20: Lateral view of the female thorax. 21: Head and antenna (the left one is omitted) of the female. 
notum distinctly truncate ; notauli indicated on posterior $1 / 2$ of mesonotum, absent anteriorly; median lobe projecting posteriorly, broadly covering the depressed base of scutellum; scutellar foveae deep, filled with scale-like pubescence ; mesopleuron weakly impressed medially; metapleuron pubescent. Wings veinless; length : width of forewing, $1.07: 0.45$, length : width of hind wing, 0. 95 :0. 2. Tarsi 5-segmented.

Abdomen: Margined at sides ; length : width of each tergite, I $0.12: 0.17$, II $0.4: 0.32$, III $0.04: 0.29$, IV $0.05: 0.24$, V 0. 06: 0. 19, VI 0. $12: 0.14$.

\section{M ale}

Length : $1.0-1.5 \mathrm{~mm}$.

Similar to female except antenna and abdomen. Length : width of antennal segments, I $0.23: 0.04$, II $0.061: 0.037$, III $0.043: 0.035$, IV $0.074: 0.05$, V $0.072: 0.037$, VI $0.072: 0$. 039, VII $0.065: 0.039$, VIII $0.065: 0.039$, IX $0.065:$ 0.039 , X 0.109 : 0.039; hairs of flagellum longer than in female, almost as long as width of the segment of origin (Figs. 18 and 21). Length : width of abdominal tergite, I $0.11: 0$. 15, II $0.35: 0.28$, III $0.03: 0.26$, IV $0.03: 0.23$, V 0.03 : 0. 19, VI $0.02: 0.14$, VII $0.02: 0.09$.

Type material: Holotype female (Type No. 2162, Kyushu Univ.) and 15 paratopotype females and 16 paratopotype males, Tatsudayama, Kumamoto City, Kyushu, 23. V. 1973 (Z. Kuranaga) ; 4 paratopotype females and 4 paratopotype males, 20. V. 1973 (Z. Kuranaga) ; 2 paratype females and 2 paratype males, Kamikamo, Kyoto Pref., Honshu, 18. V. 1976 (K. Sone) ; 2 paratype females and 2 paratype males, Yuza, Yamagata Pref., Honshu, V. 1976 (Z.Kuranaga); 5 paratype females and 5 paratype males, Seochun, Choong-Chungnam, Korea, 19. V. 1977 (Y. Hirashima).

Distribution: Japan (Kyushu, Honshu) and Korea.

Diagnosis: This species is very close to Platygaster sugitama which is described below, and is only separable from it by the occiput being more striated than in the latter (Figs. 17 and 24).

Biology: This is a gregarious endoparasite of the gall midge indicated above. About four adult wasps of this species can emerge from one host larva, although frequently about seven wasp larvae are seen living together in one host larva. One female wasp contains about 1,000 mature eggs in her abdomen. It oviposits in the egg of the host. The life cycle of this species is also similar to that of Inostemma seoulis and Inostemma matsutama. 


\section{W asps parasitic to Contarinia inouyei Mani, OR SU GI-TAMABAE \\ Proctotrupoidea : Platygasteridae}

\section{(1) Platygaster sugitama, new species (Figs. 22-28)}

Japanese name: スギタマヤドリハラビロコバチ

\section{Female}

Length : $1.05-1.55 \mathrm{~mm}$.

Color: Body black, shining; antenna brown; legs reddish brown; coxae reddish brown to black; basal four tarsal segments yellowish.

Head: Length in top view: height in front view : width, $0.21: 0.31$ : 0.4; mandible bidentate ; POL : LOL : OOL, 0.12 ; $0.047: 0.06$; occiput distinctly less striate than in Platygaster matsutama (Figs. 17 and 24). Antenna lo-segmented, length : width of each segment, I $0.273: 0.054$, II $0.087: 0.033$, III $0.041: 0.024$, IV $0.054: 0.03$, V $0.063: 0.03$, VI $0.072: 0.035$, VII $0.074: 0.041$, VIII 0.076 : 0.041 , IX $0.074: 0.041, x 0.109: 0.041$.

Thorax: Stout, length : height : width across tegulae, $0.49: 0.41: 0.35$; pronotum truncate ; notauli indicated on posterior $1 / 2$ of mesonotum; median lobe projecting posteriorly, covering a part of the depressed base of scutellum; median lobe on scutellar foveae variable in width, sometimes much narrower than in Platygaster matsutama; scutellum convex, without hairs in middle as in Platygaster matsutama; mesopleuron without hairs, weakly depressed ; metapleuron pubescent. Wings veinless; length : width of forewing, $1.1: 0.47$, length : width of hindwing, $0.94: 0.19$. Tarsi 5-segmented.

Abdomen: Margined at sides ; length : width of each tergite, I $0.09: 0.11$, II $0.37: 0.3$, III $0.05: 0.28$, IV $0.06: 0.25, \mathrm{~V} 0.07: 0.2$, VI $0.1: 0.14$; tergite VI triangular, pointed apically.

\section{Male}

Length : 1.0 - $1.3 \mathrm{~mm}$.

Similar to female except antenna and abdomen. Length : width of each antenna1 segment, I $0.23: 0.04$, II $0.06: 0.037$, III $0.043: 0.035$, IV $0.074: 0.05$, V $0.072: 0.037$, VI $0.072: 0$. 039, VII $0.065: 0.039$, VIII $0.065: 0.039$, IX $0.065:$ 0.039 , X $0.109: 0.039$; hairs of flagellum longer than female, almost as long as the width of the segment of origin (Figs. 25 and 28). Length : width of abdominal tergites, I $0.11: 0$. 15, II $0.35: 0.28$, III $0.03: 0.26$, IV $0.03: 0.23, \mathbf{v} 0.03$ : 0.19 , VI $0.02: 0.14$, VII $0.02: 0.19$.

Type material: Holotype female (Type No. 2163, Kyushu Univ.) and 9 paratopotype females, Tatsudayama, Kumamoto City, Kyushu, 22. IV. 1976 (N. Yoshida) ; 13 paratopotype females, 19. IV. 1976 (N. Yoshida) ; 7 paratopotype females, 21. IV. 1976 (N. Yoshida) ; 3 paratype females, Kikuchi, Kumamoto 

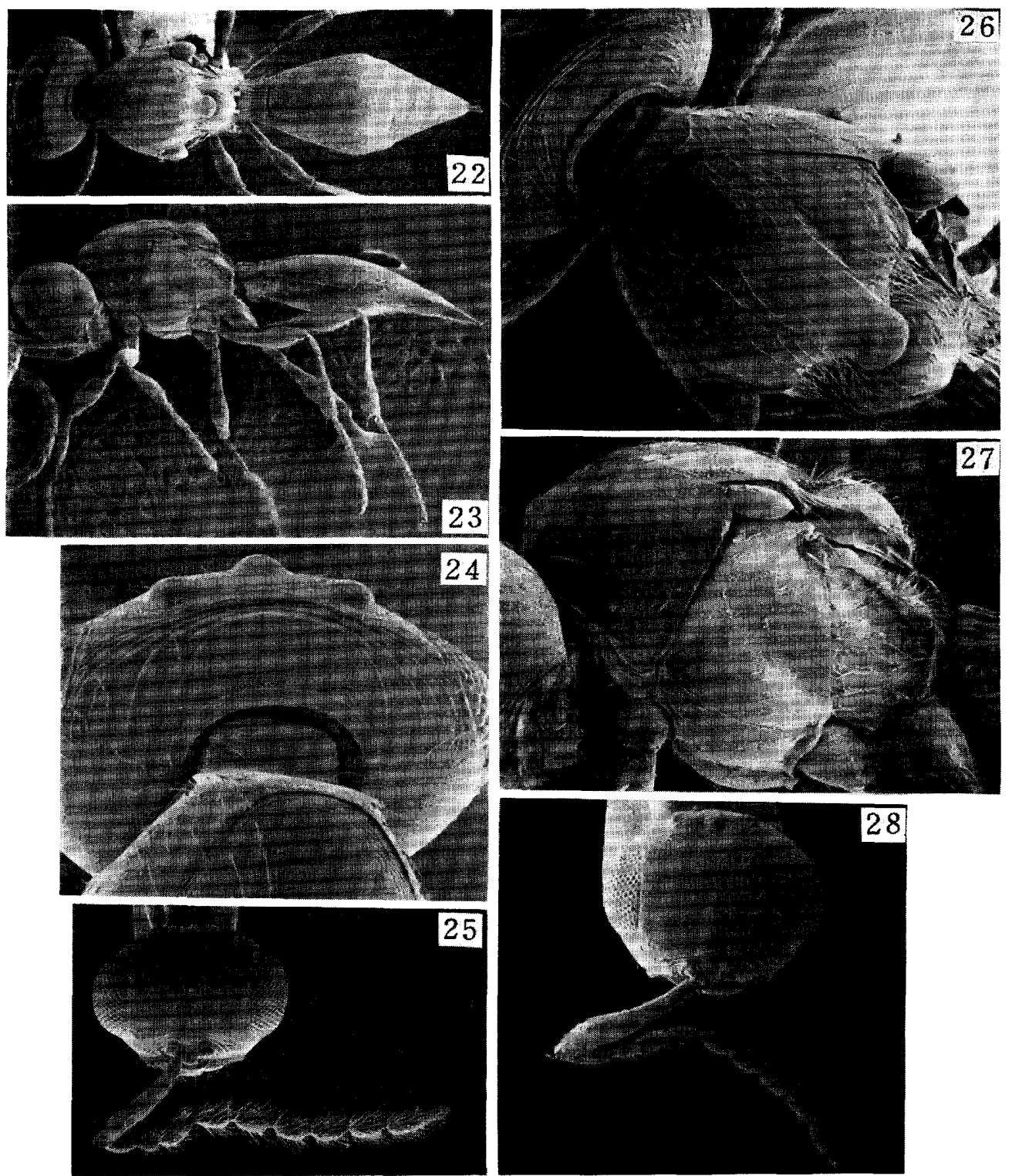

Figs. 22-28. Platygaster sugitama, new species. 22: Dorsal view of the female. 23: Lateral view of the female. 24: Occiput of the male. 25: Head and antenna (the left one is omitted) of the male. 26: Dorsal view of the female thorax. 27: Lateral view of the female thorax. 28: Head and antenna (the left one is omitted) of the female. 
Pref., Kyushu, 18. IV. 1976 (N. Yoshida) ; 5 paratype males, 19. IV, 1973, 5 paratype males, 17. IV. 1976, 8 paratype males, 18. IV. 1976, and 2 paratype males, 19. IV. 1976, same locality as above, all were collected by N. Yoshida.

Distribution: Japan (Kyushu).

DIAGivosis: As stated in the text, the present new species is very close to Platygaster matsutama, and is only separable from the latter in having the occiput distinctly less striated in both sexes.

BIOLOGY: This is a gregarious endoparasite of the gall midge stated
above. About four adult wasps can emerge from one host larva. Adult
wasps appear about one month earlier than Platygaster matsutama does. The
life span of the adult wasp is very short, at most two or three days, often
a day. A female wasp contains about 900 mature eggs in her abdomen,
and oviposits in the egg of the host. The full-grown larvae of the host,
which are in the third instar larval stage, drop to the ground in October in
Kyushu and overwinter in the soil. They pupate in the soil in April, and the
adults appear soon after. The larvae of the wasp also pupate in March and
April.

Chalcidoidea : Pteromalidae

(2) Gastrancistus sugitama, new species (Figs. 29-35)

Japanese name：スギタマヤドリコガネコバチ

\section{Female}

Length : $1.5-1.9 \mathrm{~mm}$.

Color: Distinctly metallic, golden green or frequently more coppery; mandible yellow; antennae yellow or slightly brownish except scape; legs yellow, coxae brownish ; hind femora broadly brownish medially; mid and fore femora sometimes brownish medially.

Head: Ratio of height in front view : length in top view : width, $0.35: 0.22$ : 0.48 ; genae short ; anterior margin of clypeus curved forward and slightly truncate medially; lower edge of antenna1 toruli slightly lower than level of ventral edge of eyes, separated 1.5 times as long as own diameter from clypeus ; inner orbits of eye diverging only slightly ventrad; mandible with four teeth, the uppermost tooth slightly smaller than others. Antenna 12-segmented; formula 11253; combined length of pedicellus and flagellum at most equal to breadth of head; scape shorter than eye, not reaching median ocellus; anelli 2-segmented, discoid, the basal one very minute ; first and second segments of funicle longer than broad; length : width of antenna1 segments, I $0.187: 0$. 037, II $0.059: 0.041$, III $0.003: 0.022$, IV $0.005: 0.022$, V $0.052: 0.039$, VI $0.05: 0.039$, VII $0.052: 0.043$, VIII $0.064: 0.054$, IX $0.05: 0$. 054 , X $0.044:$ 0. 059, XI 0. $044: 0.056$, XII 0. $036: 0.043$.

Thorax: Pronotal collar broadly rounded in front ; mesoscutum reticulate, 

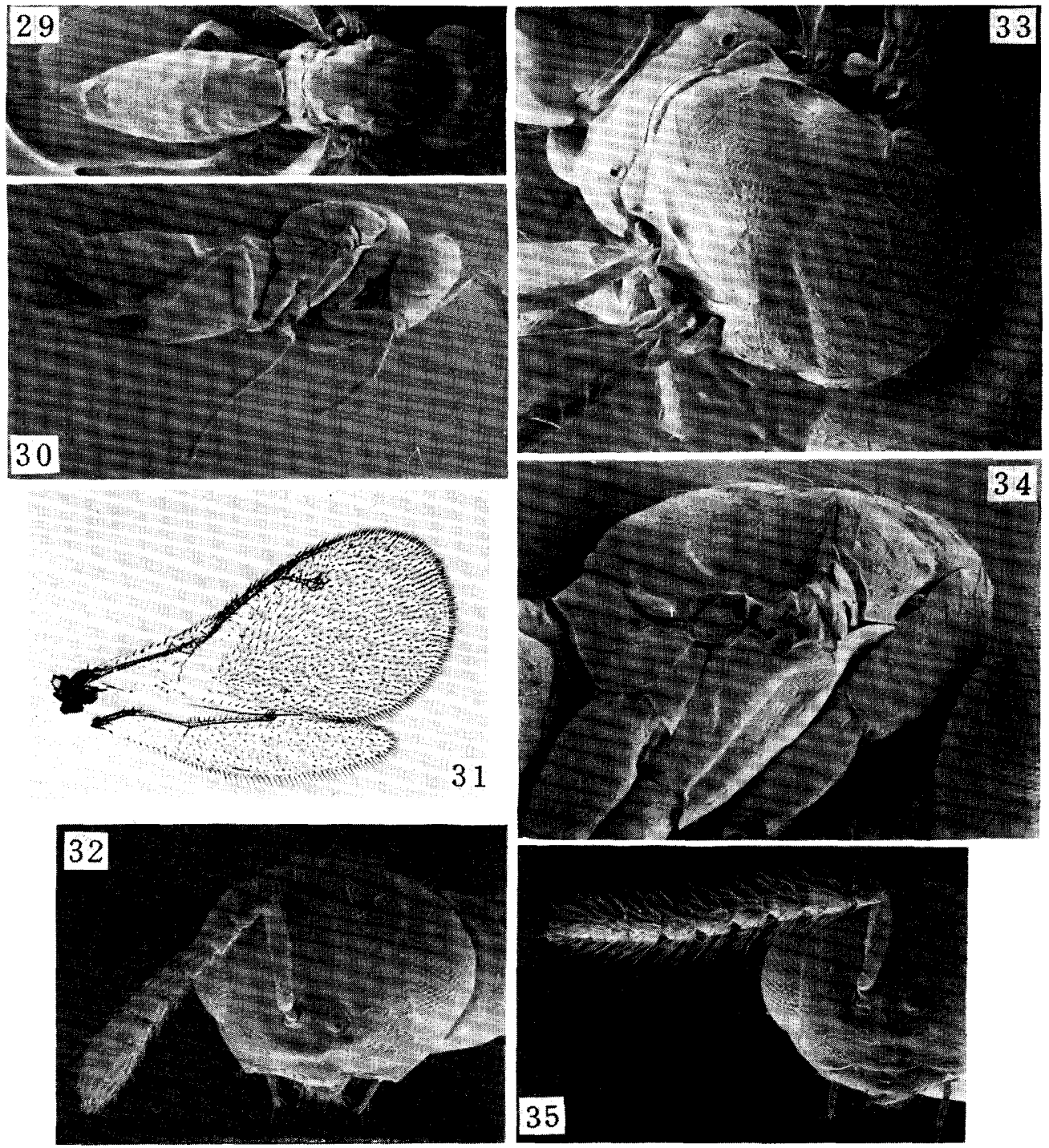

Figs. 29-35. Gastrancistus sugitama, new species. 29: Dorsal view of the female. 30 : Lateral view of the female. 31: Wings. 32: Head and antenna (the left one is omitted) of the female. 33: Dorsal view of the female thorax. 34: Lateral view of the female thorax. 35: Head and antenna (the left one is omitted) of the male. 
with sparse bristles; notauli complete, almost straight ; scutellum slightly shorter than mesoscutum, longer than broad, sculptured like mesoscutum and with 3 paires of bristles; frenum marked off by a fine grooved line; scutelloaxillar sutures meet mesoscutum a little mesad of hind ends of notauli; axillae sculptured like scutellum; dosellum smooth, shorter than frenum; propodeum strongly transverse, about $1 / 5$ as long as scutellum, weakly reticulate, without median carina; spiracles circular, separated from metanotum by nearly own diameter; callus with five to six bristles; metapleuron narrowing dorsally; mesepimeron elongate, weakly reticulate and marked off from mesepisternum; upper triangular area of mesepisternum wholly smooth, lower area reticulate. Legs not stout; hind coxae about 2.5 times as long as broad, reticulate, dorsal surface without hairs; spur of mid tibia about half as long as first tarsal segment ; tarsi 5-segmented. Forewing slightly more than twice as long as broad ; costal cell broad (length : breadth, about $9: 1$ ), its lower surface sparsely hairly, its upper surface with a row of several hairs in distal third; upper surface of basal cell with several hairs in distal end; speculum opened below, extending as a bare strip to marginal vein; radial cell hairy, as dense as disc ; marginal vein 1.4 times as long as postmarginal vein and 1.9 times as long as stigma1 vein; stigma moderate in size, oval, with a distinct uncus.

Abdomen : Elongated obovate ; abdomen strongly compressed laterally and very thin as seen from above in ordinarily dried specimens; abdomen 1.7 times as long as thorax; petiol very short but visible dorsally, 0. 5 times as long as propodeum; basal foveae not distinct; ovipositor sheath projecting, as long as the last tergite; hypopygium extending half way along the abdomen, without mucro.

\section{Male}

Length : $1.1-1.7 \mathrm{~mm}$.

Differs from the female in antennae and abdomen. Antenna1 formula 11262; antenna yellow, pedicellus blackish basally; length : width of antenna1 segments, I $0.167: 0.041$, II $0.054: 0.043$, III 0 . $003: 0.022$, IV $0.005: 0.022$, V $0.065: 0.046$, VI $0.061: 0.052$, VII $0.054: 0.052$, VIII $0.054: 0.052$, IX 0.054 : 0.052 , X $0.059: 0.052$, XI $0.054: 0.052$, XII $0.065: 0.043$. Abdomen elongated ovate; slightly longer than thorax; basal tergite with distinct Y-shaped fovea.

Type material: Holotype female (Type No. 2164, Kyushu Univ.) and 19 paratopotype females and 20 paratopotype males, Tatsudayama, Kumamoto City, 2. V. 1975 (N. Yoshida) ; 8 paratopotype females and 8 paratopotype males, 10. V. 1975 (N. Yoshida) ; 11 paratopotype females and 7 paratopotype males, 17. V. 1979 (N. Yoshida).

A long series of female and male specimens other than the type material is also examined.

DistRibution : Japan (Kyushu only). 

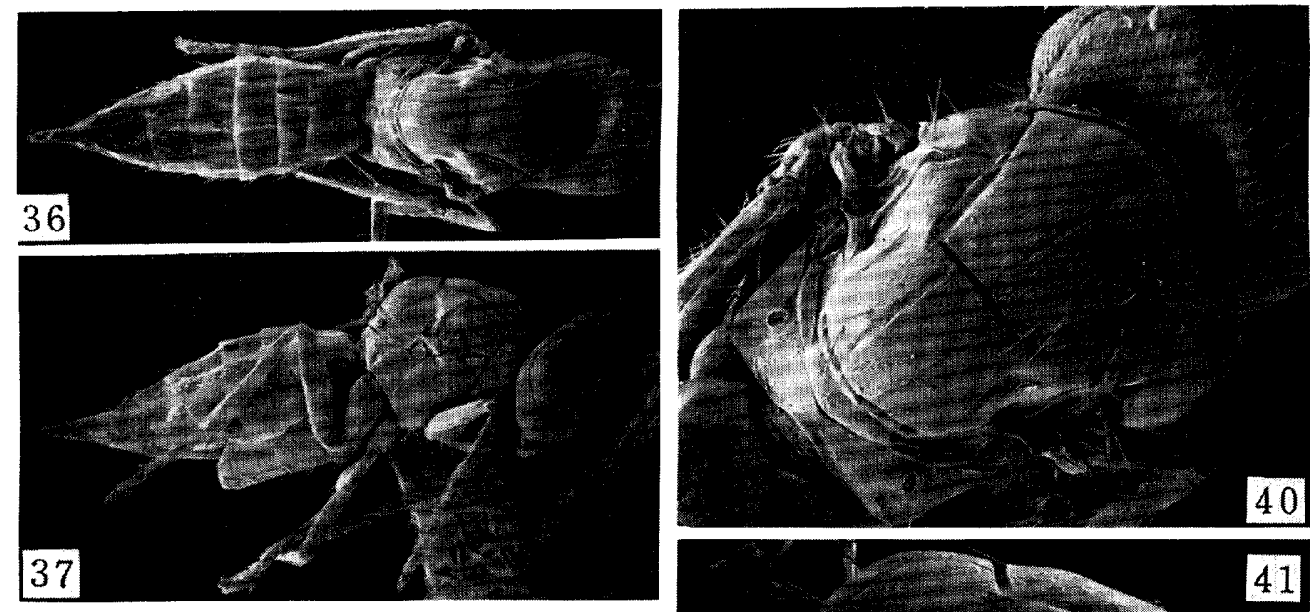

\section{7}
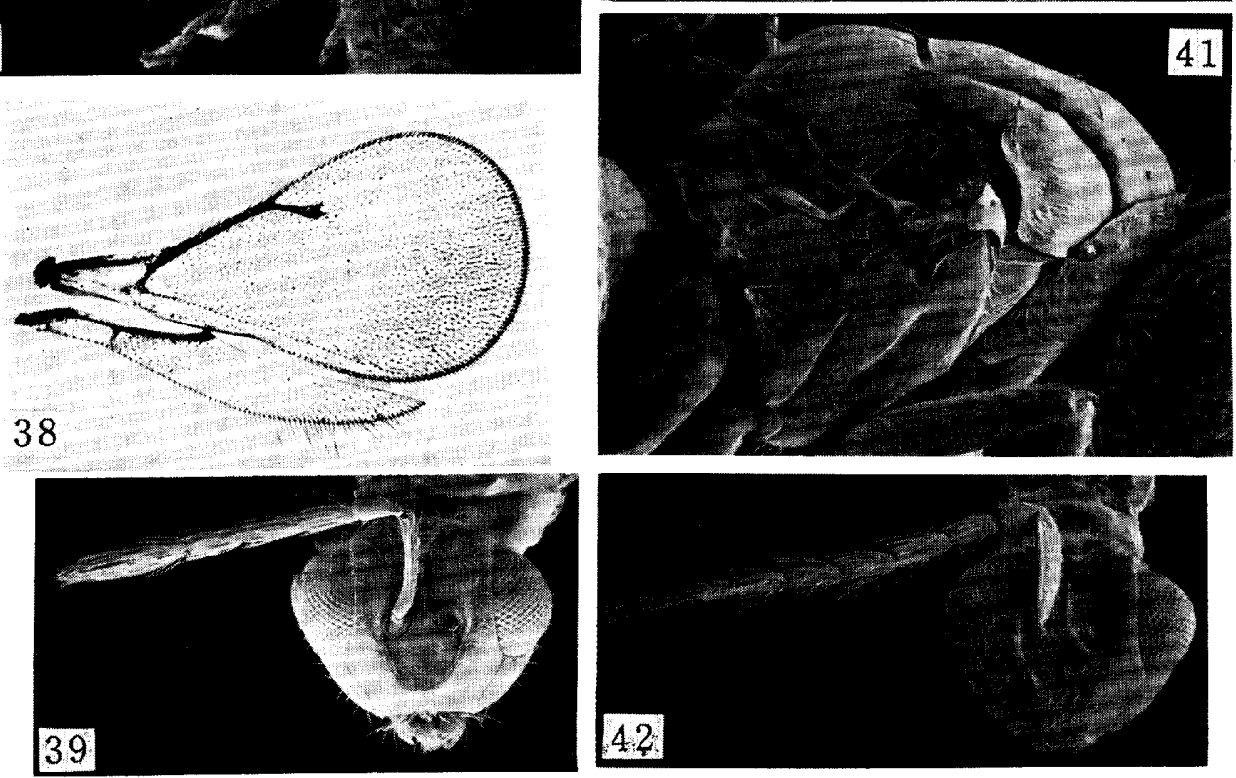

Figs. 36 -42. Tetrastichus sugitamabae Yasumatsu et Yoshii. 36: Dorsal view of the female. 37: Lateral view of the female. 38: Wings. 39: Head and antenna (the left one is omitted) of the female. 40: Dorsal view of the female thorax. 41 : Lateral view of the female thorax. 42: Head and antenna (the left one is omitted) of the male. 
Diagnosis: The antenna1 formula of this species is unique and the proportion of each antenna1 segment easily separates this new species from the congeneric species.

Brozogy: This new species is a solitary endoparasite of the midge shown above. Only one larva lives in one host larva. The female wasp apparently does not oviposit in the eggs of the host which were already oviposited by Platygaster or Tetrastichus. Adult wasps fly in May. The life span of them is about 40 days. A female wasp has about 200 eggs in her abdomen. Apparently the first instar larva of the host is chosen for oviposition. The wasp overwinters in the larval stage in the host larva in the soil and pupate toward April.

\section{Chalcidoidea : Eulophidae}

(3) Tetrastichus sugitamabae Yasumatsu et Yoshii

(Figs. 36-42)

Japanese name: スギタマヤドリヒメコバチ

Tetrastichus sugitamabae Yasumatsu et Yoshii, 1959, Bull. Fac. Agr., Kyushu Univ., 17 (2) : 168, female and male. Type locality : Nobeoka, Kyushu

Biology of this parasite was studied by Yoshii (1959). The adult wasps of Tetrastichus sugitamabae emerge from the host larva all year round, but most frequently in October and early November (57 \%); the sex ratio being $65 \mathrm{fe}-$ males and 35 males. The life span of a male reared in a test tube with honey was 89 days (from March 26 to June 22). More observations were made by Kobayashi (1966) who concluded that this parasite is synovigenic and the egg is anhydropic.

Although this species was originally found in Kyushu, it occurs throughout Japan except Hokkaido.

\section{IiI. Wasp parasitic to Resseliella odai ( Inouye),} OR SUGIZAI-NO-TAMABAE

\section{Proctotrupoidea : Platygasteridae}

(1) Synopeas zaitama, new species (Figs. 43-49)

Japanese name :ザイタマヤドリハラビロコバチ

\section{Female}

Length :1.35 - $2.30 \mathrm{~mm}$.

Color: Body black; antenna reddish brown with club darker; legs reddish brown except coxae nearly black and femora often darkened.

Head: Transverse in front view; length in top view : height in front view: width, $0.23: 0$. $355: 0.435$; head distinctly reticulate, not shining. Eyes oval, height : width, $0.2: 0.16$; POL: LOL : OOL, 0.15:0.07:0.06. Antenna 10segmented, length : width of each segment, I $0.315: 0.08$, II $0.087: 0.037$, III 

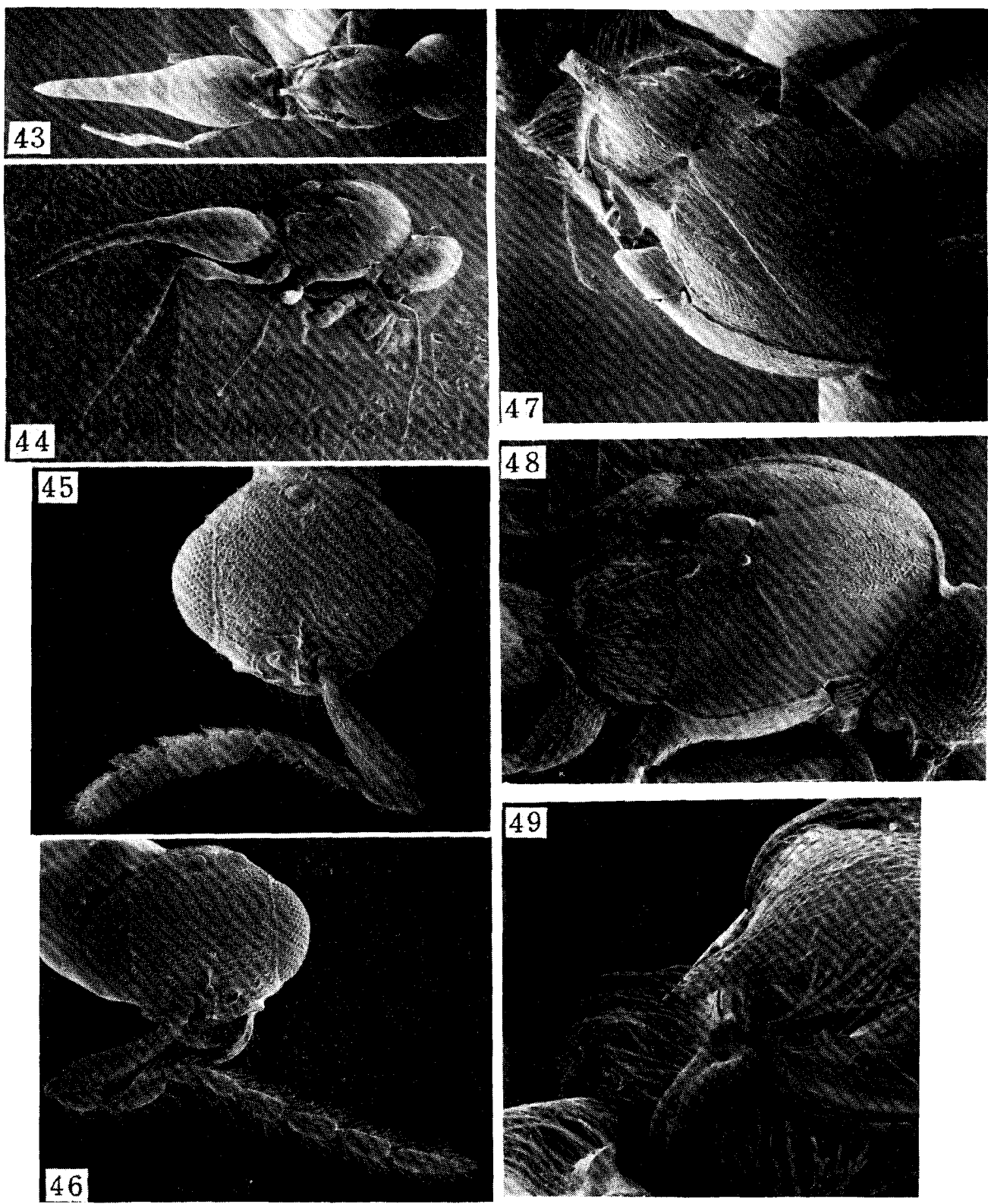

Figs. 43-49. Synopeas zaitama, new species. 43: Dorsal view of the female. 44 : Lateral view of the female. 45: Head and antenna (the right one is omitted) of the female 46: Head and antenna (the left one is omitted) of the male. 47: Dorsal view of the male thorax. 48: Lateral view of the male thorax. 49: Posterior part of the male thorax, an oblique-dorsal view. 
$0.046: 0.028$, IV $0.078: 0.024$, V $0.056: 0.028$, VI $0.043: 0.03$, VII $0.085: 0.069$, VIII $0.078: 0.069$, IX $0.078: 0.069, \mathrm{X} 0.106: 0.056$.

Thorax: Ratio of length : width : height, $0.6: 0.38: 0.46$; collar of pronoturn truncate, about half as wide as thorax; notauli indicated on posterior $3 / 4$ of mesonotum; median lobe of mesonotum projecting posteriorly and slightly covering depressed base of scutellum; scutellum convex, with a posteriorly projecting horn (Fig. 47) ; propodeum with long hairs (Fig. 49) ; mesopleuron bare, partly weakly depressed; metapleuron covered with long hairs ; thorax reticulate dorsally, only weakly shining; meso- and metapleura polished and strongly shining. Wings veinless; length : width of forewing, 1.46 : 0.58 ; length : width of hind wing, 1.25 : $\mathbf{0 . 2 3}$.

Abdomen: Tergite I transverse, covered with dense white hairs ; tergites IV and $\mathrm{V}$ elongate ; length : width of each tergite, I $0.04: 0.14$, II $0.46: 0.32$, III $0.13: 0.22$, IV $0.16: 0.15$, V $0.25: 0.11$, VI $0.21: \mathbf{0 . 0 8}$; abdomen shining, especially so on tergite II which is polished, the following tergites finely sculptured except apical margins.

Male

Length : $1.23-1.62 \mathrm{~mm}$.

Similar to female except antenna and abdomen. Length : width of antennal segments, I $0.31: 0.073$, II $0.082: 0.046$, III $0.042: 0.033$, IV $0.01: 0.061$, V $0.061: 0.04$, VI $0.09: 0.04$, VII $0.096: 0.047$, VIII $0.101: 0.045$, IX $0.1: 0.045$, X $0.138: 0.038$. Abdomen not elongate ; length : width of abdominal tergites, I $0.04:$ 0. 12 , II $0.38: 0.28$, III $0.04: 0.22$, IV $0.06: 0.18$, V $0.06: 0$. 15 , VI $0.06:$ 0.1 .

Type material: Holotype female (Type No. 2165, Kyushu Univ.) and 19 paratopotype females and 2 paratopotype males, Ebino, Miyazaki Pref., Kyushu, 29. V. 1979 (T. Sanui) ; 5 paratopotype females, V-VI. 1977 (T. Sanui) ; 3 paratopotype females, 24. V. 1978 (T. Sanui).

Distribution : Japan (Ebino, Miyazaki Prefecture, Kyushu only).

DiAgnosis: The proportions of the antennal segments and abdominal tergites are characteristic to this species which separate this from the congeneric species.

Brotogy: This new species is the only wasp parasitic to Resseliella odai (Inouye). The adult wasps appear twice a year while the host passes a generation a year. This is probably a solitary endoparasite (Sanui, 1978). The distribution of this species is very limited, known only from Ebino, Miyazaki Prefecture, Kyushu so far. So far as we know, the male of this species is very few in number.

\section{Literature}

Ashmead, W. H. 1893. Monograph of the North American Proctotrupidae. Bull. U. S. 
Nat. Mus., 45: 1-457.

Ashmead, W. H. 1903. Classification of the pointed-tailed wasps, or the superfamily Proctotrupoidea. J. N. Y. Ent. Soc., 11: 86-99.

Fouts, R. M . 1924. Revision of the North American wasps of the subfamily Platygasterinae. Proc.U. S. Nat. 'Mus. 63 (15) : 1-145.

Graham, M. W. R. de V. 1969. The Pteromalidae of Northwestern Europe (Hymenoptera : Chalcidoidea). Bull. Brit. Mus. (Nat. Hist.) Ent.Suppl. 16: 1-308.

加藤銈治 (Kato, K.). 1964. 針葉樹のタマバエ類害虫の寄生峰に関する研究. 神奈川県林業指導所報 告, (11) : 17-36.

Kieffer, J. J. 1926. Scelionidae. Das Tierreich, 48: 1-885.

Ko, J. H. 1963. Studies on the ecology of Isostasius sp., the larval parasite of pine gallmidge (Thecodiplosis pinicola Takagi). Res. Rep. Office Rural Devel., Suwon, 6 (2) : 91-95. (In Korean with English summary)

Ko, J. H. 1965. Studies on the Isostasius seoulis (sp. nov.), the larval parasite of pine gallmidge (Thecodiplosis japonensis Uchida et Inouye). Taxonomical and morphological studies. Res. Rep. Office Rural Devel., Suwon, 8 (2) : 91-96. (In Korean with English summary)

Ko, J. H. 1965. Studies on the Isostasius seoulis Ko, the larval parasite of pine gail-midge (Thecodiflosis japonensis Uchida et Inouye) II. Res. Rep. Office Rural Devel., Suwon, 8 (2) : 97-101. (In Korean with English summary)

Ko, J. H. 1966. Studies on the Isostasius seoulis Ko, the larval parasite of the pine gallmidge (Thesndiplosis japonensis Uchida et Inouye) (3). Res. Rep. Office Rural Devel., Suwon, 9 (2): 59-67. (In Korean with English summary)

Kc, J. H. and B. Y. Lee. 1971. Studies on the utilization of the hymenopterous parasites (Isostasius seoulis Ko and Platygaster sp.) of pine gall-midge. Res. Rep. Forest Res. Inst., (18) : 85-94. (In Korean with English summary)

Kobayashi, M. 1964. On the site and numbers of eggs oviposited by Platygaster sp. and Inostemma sp., the parasites of Contarinia inouyei Mani. Proc. Assoc. PZ. Prot. Kyushu, 10: 67-69. (In Japanese with English summary)

Kobayashi, M . 1966. Oögenesis and oösorption of Tetrastichus sugitamabae Yasumatsu et Yoshii (Hymenoptera, Eulophidae). a parasite of Contarinia inouyei Mani (Diptera, Cecidomyiidae). Sci. Bull.Fac. Agr., Kyushu Univ., 22 (3) : 311-318. (In Japanese with English summary)

Kozlov, M. A. 1970. Supergeneric groupings of Proctotrupoidea (Hymenoptera). Rev.ent. URSS, 69 (1) : 203-229. (In Russian)

Kozlov. M. A. 1971. Proctotrupoids (Hymenoptera, Proctotrupoidea) of the USSR. Horae Sac. Ent. Uni. Sov., 54: 3-67. (In Russian)

倉永善太郎 (Kuranaga，Z.). 1974 a. マッバ/タマバエの生態に関する研究一寄生蜂の飼育試験一. 日林九支研論集, (27) : 147-148.

倉永善太郎 (Kuranaga，Z.). 1974 b. マッバノタマバエ天敵の大量採集と保存法. 昭 48 林試九支場 年報, (16) : 40 .

倉永善太郎。吉田成章・森本桂 (Kuranaga, Z., N. Yoshida and K. Morimoto). 1972. タマバ 工類の総合的防除法汇関する研究. 昭 46 林試九支場年報, (14): 90-91.

倉永善太郎。吉田成章 - 森本 桂 (Kuranaga, Z.. N. Yoshida and K. Morimoto). 1973. 対馬に 招けるマッバノタマバエ被害と天敵寄生率の変動. 第a4 回日林学会大会講演集,pp. 343-344.

倉永善太郎.吉田成章・森本桂 (Kuranaga, Z., N. Yoshida and K. Morimoto). 1976. 7 ッバ ノタマバエの生態に関する研究 (IV) 一低密度林におけるマッバノタマバエ寄生蜂の役割一. 日林九 支研論集, (29)：237-238.

Masner, L. 1964. A comparison of some Nearctic and Palearctic genera of Proctotrupoidea (Hymenoptera) with revisional notes. Cas. Cs. Spol. ent. (Acta Soc. ent. Cechosl.), 54 (2) : 123-155.

松枝章 (Matsueda， A.). 1966. 7 ツバノタマバエの天敵による防除試験. 石川県林試研報, (4)： 
163-172.

Miura, T. 1962. Studies on Thecodiposis japonensis Uchida et Inoue and its important parasite, Platygaster sp. $186 \mathrm{pp}+18$ pls. Shimane Forest Experiment Station, Matsue. (In Japanese with English summary)

濽井孝義 (Sanui，T.). 1978 . スギザイノタマバェの天敵に関する研究 (III) 一笴生蜂について一.日 林九支研論集, (31) : 237-238.

山田栄一( Y Y mada, E.). 1963. 針葉樹のタマバエ類害虫（特にマッバノタマバェ）の天敵調查. 島根 県林試 25 周年記念論文集, pp. 691-710.

安松京三 (Yasumatsu, K.). 1961. 針葉樹のタマバエ類害虫の天敵調査に関する咞究. 4 pp. +4 pls. 昭和 35 年度農林漁業試験研究費補助金による研究報告書.

安松京三 (Yasumatsu, K.). 1964. スギタマヤドリヒメコバチの大量生産に関する研究. 熊本営林局 造林情報, 9 (4) : 3-5。

Yasumatsu, K. and T. Yoshii. 1959. Tetrastichus sugitamabae sp. nov., an important parasite of Contarinia inouyei Mani in Kyushu, Japan (Hymenoptera, Eulophidae). Sci. Bull. Fac.Agr.,Kyushu Univ., 17 (2) : 167-170. (In Japanese with English description)

吉井宅男 (Yoshii，T.). 1959. スギタマバエの天敵について(付・スギのカイガラ 4 シ類の天敵). 12 P P. + 3 pls. 熊本営林局.

\section{APPENDIX}

1. The fourth species of gall midge injurious to the conifers in Japan is the Japanese pine bud gall midge or matsu-no-shintome-tamabae, Contarinia matsusintome Haraguti et Monzen which attacks the pine trees. This species, however, is a minor pest. Yasumatsu (1961) recorded two Hymenopterous parasites, Tetrastichus sp., which was said to be slightly larger than Tetrastichus sugitamabae Yasumatsu et Yoshii, and Brachyinostemma sp. No further information is available on these Hymenopterous species.

2. Inostemma sp. parasitic to sugi-tamabae which was recorded by Kobayashi (1964) was not discovered in the course of the present study. Thus, the occurrence of this parasite is not confirmed.

3. "X kobachi" of Yoshii (1959) is described as Gastrancistus sugitama in this paper.

4. What was recorded as "Platygaster sp. parasitic to sugi-tamabae and matsuba-no-tamabae" in Japanese literatures is recognized as a mixture of two species, which are described as Platygaster sugitama and Platygaster matsutama in this paper. As a matter of fact, these two species are very similar to each other.

5. In pine forests of Japan and Korea, another species of Inostemma sp., which has a very long projection on the tergite I, has been collected by sweeping together with Inostemma seoulis. We are not certain, however, whether this species is also parasitic to matsuba-no-tamabae or not.

6. Another species of Platygaster living in pine forests, a few specimens of which have been taken in Japan and Korea, is suspicious of its parasitic habit to matsuba-no-tamabae. This species is known by the tergites IV and $\mathrm{V}$ being distinctly elongate. 